\title{
Antimicrobial and antioxidant activities of the extracts and compounds from the leaves of Psorospermum aurantiacum Engl. and Hypericum lanceolatum Lam.
}

Patricia D Tchakam ${ }^{1}$, Paul K Lunga ${ }^{1,2}$, Théodora K Kowa ${ }^{3}$, Antoine Honoré N Lonfouo ${ }^{3}$, Hippolyte K Wabo ${ }^{3}$, Léon A Tapondjou ${ }^{3}$, Pierre Tane ${ }^{3}$ and Jules-Roger Kuiate ${ }^{1^{*}}$

\begin{abstract}
Background: Psorospermun aurantiacum and Hypericum lanceolatum are plants locally used in Cameroon and other parts of Africa for the treatment of gastrointestinal and urinary tract infections, skin infections, venereal diseases, gastrointestinal disorder, infertility, epilepsy as well as microbial infections. The present study was designed in order to investigate the in vitro antimicrobial and radical scavenging activities of the extracts and isolated compounds from the leaves of these plants.

Methods: The plant extract was prepared by maceration in ethyl acetate and methanol and fractionated by column chromatography. The structures of isolated compounds were elucidated by spectroscopic analyses in conjunction with literature data. The broth microdilution method was used to evaluate the in vitro antimicrobial activity against bacteria, yeasts and dermatophytes. The antioxidant potentials of the extracts and their isolated compounds were evaluated using the DPPH radical scavenging method.

Results: Five known compounds: physcion (1), 1,8-dihydroxy-3-geranyloxy-6-methylanthraquinone (2), kenganthranol B (3), vismiaquinone (4), and octacosanol (5) were isolated from the leaves of $P$. aurantiacum while six compounds including friedelin (6), betulinic acid (7), 2,2,5,6'-tetrahydroxybenzophenone (8), allanxanthone A (9), 1,3,6- trihydroxyxanthone (10) and isogarcinol (11) were isolated from $\mathrm{H}$. lanceolatum. Compound 8 and 4 exhibited the highest antibacterial and antifungal activities with MIC ranges of $2-8 \mu \mathrm{g} / \mathrm{ml}$ and $4-32 \mu \mathrm{g} / \mathrm{ml}$ respectively.

P. aurantiacum crude extract (Rsa50 $=6.359 \pm 0.101$ ) showed greater radical scavenging activity compared with H. lanceolatum extract ( $\mathrm{Rsa} 50=30.996 \pm 0.879$ ). Compound 11 showed the highest radical scavenging activity $\left(\mathrm{RSa}_{50}=1.012 \pm 0.247\right)$ among the isolated compounds, comparable to that of L-arscobic acid (RSa50 $=0.0809 \pm 0.045)$.
\end{abstract}

Conclusions: The experimental findings show that the ethyl acetate and methanol extracts and isolated compounds from $P$. aurantiacum and $H$. lanceolatum stem bark possess significant antimicrobial and antioxidant activities justifying the use of these plants in traditional medicine, which may be developed as phytomedicines.

\footnotetext{
* Correspondence: jrkuiate@yahoo.com

'Laboratory of Microbiology and Antimicrobial Substances, Department of Biochemistry, Faculty of Science, University of Dschang, P.O. Box 67,

Dschang, Cameroon

Full list of author information is available at the end of the article
} 


\section{Background}

During the last 20 years, it has been reported that human infections are increasing at an alarming rate, especially in tropical and subtropical developing countries [1]. This is partly due to the indiscriminate use of antimicrobial drugs and the development of microbial resistance to some of the synthetic drugs [2]. Resistance to most antibiotics occurs through the aegis of extremely efficient enzymes, efflux proteins and other transport systems that often are highly specialized towards specific antibiotic molecules [3]. The fact that microorganisms nowadays tend to develop resistance towards drugs, coupled to the undesirable side effects of certain antibiotics offer considerable potentials for the development of new effective antimicrobial agents; medicinal plants being a prolific source. Various plant extracts possess bacteriostatic and bactericidal effects due to secondary metabolites they contain, namely alkaloids, tannins, flavonoids, and phenolic compounds. Most of these secondary metabolites other than possessing antimicrobial potential, can also act as potent antioxidants [4].

Psorospermun aurantiacum and Hypericum lanceolatum are trees, both belonging to the family of Guttiferae and are generally found in mountainous areas [5]. In Cameroon, Psorospermun aurantiacum appears in the North-West and West Regions, where the decoction of the leaves is used to treat gastrointestinal and urinary tract infections. Combined with other plant extracts, the stem bark is used to treat epilepsy. The fruits of this plant have been recently investigated for their phytochemical constituents [6]. $\mathrm{Hy}$ pericum lanceolatum on the other hand, occurs on mountains in the Western Region of Cameroon, and is used for the treatment of skin infections, venereal diseases, gastrointestinal disorder, tumours, infertility and epilepsy [5,7]. Higher plants like those from the Guttiferae family are rich sources of antimicrobial phenolic secondary metabolites which are able to act as reducing agents, hydrogen donors, and singlet oxygen quenchers [8-11].

Several antifungal [1], antibacterial [12,13], anticancer [14,15] and antiviral [16] compounds have been isolated from Hypericum genus. In the present paper, we report the isolation of constituents from Hypericum lanceolatum and Psorospermun aurantiacum together with some related antimicrobial and antioxidant activities of these constituents and the crude extracts.

\section{Methods}

Plant material

The leaves of Psorospermum aurantiacum and Hypericum lanceolatum were separately collected in May 2009 at Mount Bamboutos, West Region of Cameroon. Authentification of the plants was done by Mr. Nana Victor at the Cameroon National Herbarium where voucher specimens were kept under the reference numbers of $52651 \mathrm{HNC}$ and $32356 \mathrm{HNC}$ respectively.

\section{Extraction, fractionation and isolation}

The air-dried and powdered leaves of $P$. aurantiacum $(2.60 \mathrm{~kg})$ and of $H$. lanceolatum $(2.00 \mathrm{~kg})$ were extracted respectively with EtOAc and $\mathrm{MeOH}$ at room temperature $(3 \times 12 \mathrm{l}, 72 \mathrm{~h})$ to obtain corresponding crude extracts of $77 \mathrm{~g}$ and $60 \mathrm{~g}$ after evaporation under vacuum. The two solvents were selected based on their extraction yields from preliminary extractions studies. Part of the crude extract of $P$. aurantiacum (67 g) was subjected to silica gel column chromatography, eluted with gradients of $n$-hexane-CH2Cl2 (10:0, 9:1, 8:2, $1: 1 ; 0: 10)$ and $\mathrm{CH} 2 \mathrm{Cl} 2$ $\mathrm{MeOH}(9: 1,8: 2,1: 1 ; 0: 10)$. Twenty three (23) fractions of $500 \mathrm{ml}$ each were collected and grouped on the basis of their thin layer chromatography (TLC) profiles into five major fractions F1-F5 (F1: 1-4; F2: 5-8; F3: 9-14; F4: 15-20 and F5: 21-23). These fractions were submitted to repeated column chromatography over silica gel and purified by preparative TLC. Octacosanol $(10 \mathrm{mg})$ was obtained from fraction F1. Fractions F2 and F3 afforded 1,8-dihydroxy-3-geranyloxy-6- methylanthraquinone $(8 \mathrm{mg})$ and vismiaquinone $(11 \mathrm{mg})$ respectively. Fraction F4 afforded kenganthranol B (10 mg) and physcion (25 $\mathrm{mg})$.

Fifty-five grams $(55 \mathrm{~g})$ of the crude extract of $H$. lanceolatum was subjected to silica gel column chromatography eluted with gradients of $n$-hexane-EtOAc (10:0, 9:1, 8:2, 1:1; 0:10) and EtOAc-MeOH (9:1, 8:2, 1:1; 0:10). Thirty-eight fractions of $500 \mathrm{ml}$ each were collected and combined on the basis of TLC analysis to afford five main fractions (A-E). Fraction A contained mostly fatty materials and was not further investigated. Fraction B was further separated by silica gel column chromatography eluted with $n$-hexane-EtOAc to give white needles of friedelin (14 mg). Betulinic acid (1.2 g) was purified from fraction $\mathrm{C}$ by recrystallization in $\mathrm{MeOH}$. Fraction $\mathrm{D}$ was submitted to a silica gel column chromatography eluted with $n$-hexane-EtOAc to afford three subfractions (D1-D3). Sub-fraction D1 was further purified by Sephadex $\mathrm{LH}-20$ using $\mathrm{CH} 2 \mathrm{Cl} 2-\mathrm{MeOH}(1: 1)$ to give 2,2,5,6'-tetrahydroxybenzophenone (30 mg). Repeated column chromatography of sub-fraction D2 on silica gel using increasing mixtures of $n$-hexane-EtOAc yielded allanxanthone A (16 mg) and 1,3,6-trihydroxyxanthone (7 mg). Isogarcinol (18 mg) was purified from sub- fraction D3 by recrystallization in $n$-hexane.

\section{Identification of isolated compounds}

The structural elucidation of compounds was done on the basis of physical data and spectroscopic analysis, including $1 \mathrm{D}$ and 2D NMR and direct comparison of the data with those reported in the literature. Melting points 
were determined with a Reichert microscope and are uncorrected. UV spectra were measured with a UV-210 PC, UV/Vis scanning spectrophotometer (Analytikjena). IR spectra were recorded on a Shimadzu FTIR-8400S spectrophotometer with $\mathrm{KBr}$. EIMS (ionization voltage $70 \mathrm{eV}$ ) and HREIMS mass spectra were recorded on Jeol JMS AX-500 and AX-700 or a 6890 N Network GC System/5975 Inert XL Mass Selective Detector GCMS spectrometers. ${ }^{1} \mathrm{H} \quad \mathrm{NMR} \quad(500 \mathrm{MHz})$ and ${ }^{13} \mathrm{C} \quad \mathrm{NMR}$ $(125 \mathrm{MHz})$ spectra were recorded in $\mathrm{CDCl}_{3}$ or $\mathrm{CDCl}_{3}$ $\mathrm{CD}_{3} \mathrm{OD}$ using a Bruker Avance $500 \mathrm{MHz}$ spectrometer. Silica gel 60 (70-230; Merck; Darmstadt, Germany) was used for column chromatography. Precoated Silica gel 60 Kieselgel $\mathrm{F}_{254}$ plates $(0.2 \mathrm{~mm}$ thick) were used for TLC, and the spots were detected with ultraviolet (UV) illumination and by spraying with $50 \%(\mathrm{v} / \mathrm{v}) \mathrm{H}_{2} \mathrm{SO}_{4}$, followed by heating at $100^{\circ} \mathrm{C}$. Merck Silica gel $60 \mathrm{~F}_{254}$ was used for preparative thin layer chromatography.

\section{Antimicrobial assay \\ Microorganisms and culture media}

The microorganisms used in this study were obtained from the American Type Culture Collection (ATCC), "Ecole Nationale Vétérinaire d'Alfort" (E), "Institut Pasteur de Paris" (IP) and "Centre Pasteur de Yaoundé". They included five bacteria species (Klebsiella pneumonia ATCC 13883, Pseudomonas aeruginosa ATCC 27853, Shigella flexneri, Salmonella typhi ATCC 6539 and Enterococcus faecalis ATCC 10541) and six fungal species (Candida lusitaniae ATCC 200950, Candida krusei ATCC 6258, Candida albicans ATCC 2091, Cryptococcus neoformans IP 95026, Trichophyton ajelloi, Trichophyton rubrum). The culture medium, Sabouraud Dextrose Agar (SDA, Conda), was used for subculturing during minimum fungicidal concentration determination. Sabouraud Dextrose Broth (SDB, Conda) was used for the determination of minimum inhibitory and fungicidal concentrations.

\section{Preparation of microbial inocula}

The inocula of bacteria and yeasts were prepared from $24 \mathrm{~h}$ old broth cultures. The absorbance was read at $600 \mathrm{~nm}$ and adjusted with sterile physiological solution to match that of a 0.5 McFarland standard solution. From the prepared microbial solutions, other dilutions with sterile physiological solution were prepared to give a final concentration of $10^{6}$ colony- forming units (CFU) per milliliter for bacteria and $2 \times 10^{5}$ spores per milliliter for yeasts.

Conidia suspensions of dermatophyte species were prepared after separation and filtration of conidia from 15 days old cultures. The number of conidia was determined using a spectrophotometer and adjusted with sterile physiological solution to an absorbance of 0.60 at
$450 \mathrm{~nm}$ corresponding to a final concentration of $1 \times 10^{5}$ spores/ml [17].

\section{Determination of minimum inhibitory concentration (MIC) and minimum microbicidal concentrations (MMC)}

The MICs of the crude extract and isolated compounds were determined by the broth microdilution method in 96-well micro-titre plates as described by Zgoda et Poter (2001) [18]. The 96-well plates were prepared by dispensing into each well $100 \mu \mathrm{l}$ of Mueller Hinton broth for bacteria and Sabouraud Dextrose broth for fungi. The test substances were initially prepared in $10 \%$ DMSO in broth medium at $4096 \mu \mathrm{g} / \mathrm{ml}$ for the extracts and $512 \mu \mathrm{g} / \mathrm{ml}$ for compounds or $50 \mu \mathrm{g} / \mathrm{ml}$ for the reference antibiotics. A volume of $100 \mu \mathrm{l}$ of each test sample was added into the first wells of the micro-titre plate (whose wells were previously loaded with $100 \mu \mathrm{l}$ of broth medium). Serial two-fold dilutions of the test samples were made and $100 \mu \mathrm{l}$ of inoculum standardized at $10^{6} \mathrm{CFU} / \mathrm{ml}$ for bacteria, $2.5 \times 10^{5} \mathrm{CFU} / \mathrm{ml}$ for yeasts (at $600 \mathrm{~nm}$, Jenway $6105 \mathrm{UV} / \mathrm{Vis}$ spectrophotometer- $50 \mathrm{~Hz} / 60 \mathrm{~Hz}$ ) [19] and $1 \times 10^{5}$ spores $/ \mathrm{ml}$ for dermatophytes (at $450 \mathrm{~nm}$ ) were then added into each well. This gave final concentration ranges of 1024 to $0.5 \mu \mathrm{g} / \mathrm{ml}$ for the extracts, 128 to $0.0625 \mu \mathrm{g} / \mathrm{ml}$ for isolated compounds and 12.50 to $0.006 \mu \mathrm{g} / \mathrm{ml}$ for reference substances. The plates were sealed with parafilm, then agitated with a plate shaker to mix their contents and incubated at $35^{\circ} \mathrm{C}$ for $24 \mathrm{~h}$ for bacteria, $48 \mathrm{~h}$ for yeast and at $28^{\circ}$ $\mathrm{C}$ for 5 days for dermatophytes.

For bacteria, MICs were determined upon addition of $50 \mu \mathrm{l}(0.2 \mathrm{mg} / \mathrm{ml}) p$-iodonitrotetrazolium chloride (INT, Sigma-Aldrich, South Africa). Viable bacteria reduced the yellow dye to a pink colour. For yeasts and dermatophytes, MICs were determined by visualising the turbidity of the wells. The MIC corresponded to the lowest well concentration where no colour/turbidity change was observed, indicating no growth of microorganism. The MBC or MFC was determined by transferring $50 \mu \mathrm{l}$ aliquots of the clear wells into $150 \mu \mathrm{l}$ of freshly prepared broth medium and incubating at $35^{\circ} \mathrm{C}$ for $24 \mathrm{~h}$ (bacteria), $48 \mathrm{~h}$ (yeasts) and at $28^{\circ} \mathrm{C}$ for 5 days (dermatophytes). The MBC or MFC was regarded as the lowest concentration of test sample which did not produce a colour/turbidity change as above, indicating no microbial growth. All tests were performed in triplicates. Ciprofloxacin for bacteria, nystatin for yeast and griseofulvin for dermatophytes were used as positives controls.

\section{Antioxidant activity}

Radical scavenging activity ( $\mathrm{RSa}$ ) of the extract and pure compounds from $P$. aurantiacum was determined using the stable free radical 2,2'-diphenylpicrylhydrazyl (DPPH) 
as described by Ghomi et al. (2008) [20]. Two-fold serial dilution was made from a $625 \mu \mathrm{g} / \mathrm{ml}$ stock solution of each sample to obtain concentration ranges of 625 to $78.12 \mu \mathrm{g} /$ $\mathrm{ml}$. A quantity of $(100 \mu \mathrm{l})$ of each test solution was mixed with $900 \mu \mathrm{l}$ of a freshly prepared DPPH-methanol solution (20 $\mathrm{mg} / \mathrm{l}$ ) and allowed to stand for $30 \mathrm{~min}$ in the dark at room temperature. The optical densities of the resulting solutions were read at $517 \mathrm{~nm}$ using a Jenway UV/vis 6105 spectrophotometer. L-ascorbic acid was used as positive control. Radical scavenging activity (RSa) was calculated as follows:

$\begin{aligned} \% R S a= & \frac{\text { Absorbance of } D P P H-\text { Absorbance of sample }}{\text { Absorbance of DPPH }} \\ & \times 100\end{aligned}$
Sample concentration providing 50\% radical scavenging activity (RSa50) was calculated from the graph of \%RSa as a function of log [sample concentration].

\section{Statistical analysis}

The data on antioxidant activity were subjected to the one-way analysis of variance (ANOVA) and results were expressed (where appropriate) as mean \pm standard deviation. Differences between means of samples were compared using Duncan's multiple range tests at $P<0.05$.

\section{Results and discussion}

The following known compounds: physcion (1) [21], 1,8dihydroxy-3-geranyloxy-6- methylanthraquinone (2) [22],

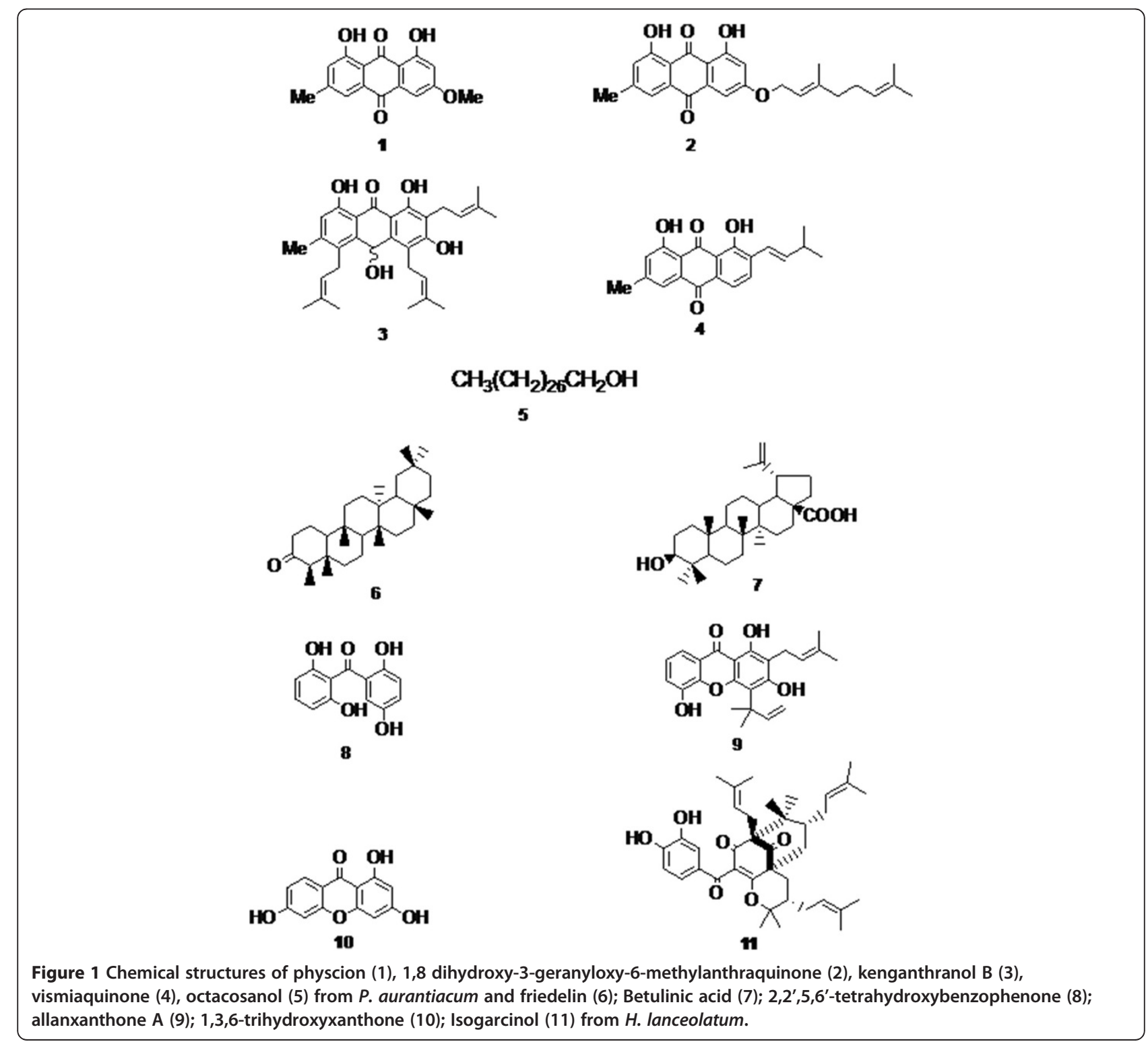


kenganthranol B (3) [6], vismiaquinone (4) [23], octacosanol (5) [24] (Figure 1) were isolated and identified in the leaves of $P$. aurantiacum. From the $\mathrm{MeOH}$ leaf- extract of $H$. lanceolatum friedelin (6) [11], betulinic acid (7) [25], 2,2,5,6'- tetrahydroxybenzophenone (8) [7], allanxanthone A (9) [26], 1,3,6-trihydroxyxanthone (10) [27] and isogarcinol (11) [28] were isolated and identified
(Figure 1). The compounds isolated in the present study were formerly isolated from other plants and diverse activities were demonstrated. H. lanceolatum extract and its isolated compounds have been proven to possess anti-malarial properties [29].

The antimicrobial properties of the extracts and isolated compounds of $P$. aurantiacum and $H$. lanceolatum

Table 1 Minimum inhibitory concentration (MIC)/Minimum bactericidal or fungicidal concentration (MBC or MFC) of tests substances $(\mu \mathrm{g} / \mathrm{ml})$

\begin{tabular}{|c|c|c|c|c|c|c|c|c|c|c|c|c|}
\hline & \multirow[b]{2}{*}{ Parameters } & \multicolumn{6}{|c|}{ P. aurantiacum } & \multicolumn{5}{|c|}{ H. lanceolatum } \\
\hline & & Extract $^{a}$ & 1 & 2 & 3 & 4 & 5 & Extract $^{b}$ & 7 & 10 & 11 & RD \\
\hline \multicolumn{13}{|l|}{ Bacteria } \\
\hline \multirow[t]{3}{*}{ K. pneumoniae } & MIC & 256 & - & 16 & 128 & 8 & 4 & 64 & 125 & 4 & 16 & 1 \\
\hline & $\mathrm{MBC}$ & 1024 & - & 32 & 128 & 16 & - & 1024 & - & 4 & 16 & 1 \\
\hline & $M B C / M I C$ & 4 & - & 2 & 1 & 2 & - & 16 & - & 1 & 1 & 1 \\
\hline \multirow[t]{3}{*}{ S. flexneri } & MIC & 1024 & - & 64 & - & 16 & 8 & 64 & 2 & 8 & 16 & 0.50 \\
\hline & $\mathrm{MBC}$ & $>1024$ & - & 64 & - & 16 & 8 & 1024 & 2 & 8 & 16 & 0.50 \\
\hline & $M B C / M I C$ & nd & - & 1 & - & 1 & 1 & 16 & 1 & 1 & 1 & 1 \\
\hline \multirow[t]{3}{*}{ P. aeruginosa } & $\mathrm{MIC}$ & 1024 & - & 32 & - & 8 & - & 64 & - & 8 & 16 & 1 \\
\hline & $\mathrm{MBC}$ & $>1024$ & - & 64 & - & 16 & - & 1024 & - & 8 & 16 & 1 \\
\hline & $\mathrm{MBC} / \mathrm{MIC}$ & nd & - & 2 & - & 2 & - & 16 & - & 1 & 1 & 1 \\
\hline \multirow[t]{3}{*}{ S. typhi } & MIC & - & - & - & - & - & 2 & 32 & 2 & 2 & 4 & 0.50 \\
\hline & $\mathrm{MBC}$ & nd & nd & nd & nd & nd & 2 & 1024 & 2 & 2 & 4 & 0.50 \\
\hline & $M B C / M I C$ & nd & nd & nd & nd & nd & 1 & 32 & 1 & 1 & 1 & 1 \\
\hline \multirow[t]{3}{*}{ E. faecalis } & MIC & - & - & - & - & nd & 32 & 64 & 32 & 8 & 32 & 0.50 \\
\hline & $\mathrm{MBC}$ & nd & nd & nd & nd & nd & 32 & 1024 & 32 & 8 & 32 & 0.50 \\
\hline & $M B C / M I C$ & nd & nd & nd & nd & nd & 1 & 16 & 1 & 1 & 1 & 1 \\
\hline \multicolumn{13}{|l|}{ Fungi/ Yeats } \\
\hline \multirow[t]{3}{*}{ C. albicans } & $\mathrm{MIC}$ & 1024 & - & - & - & 32 & - & 512 & - & 32 & 64 & 2 \\
\hline & $\mathrm{MBC}$ & $>1024$ & nd & nd & nd & 32 & - & 1024 & - & 32 & 64 & 2 \\
\hline & $M B C / M I C$ & nd & nd & nd & nd & 1 & - & 2 & - & 1 & 1 & 1 \\
\hline \multirow[t]{3}{*}{ C. Iusitaniae } & MIC & 256 & 16 & 8 & 8 & 4 & - & - & - & - & - & 1 \\
\hline & $\mathrm{MBC}$ & 256 & 16 & 32 & 16 & 8 & - & nd & - & nd & nd & 1 \\
\hline & $M B C / M I C$ & 1 & 1 & 4 & 2 & 2 & & nd & - & nd & nd & 1 \\
\hline \multirow[t]{3}{*}{ C. neoformans } & $\underline{\mathrm{MIC}}$ & 1024 & 16 & - & - & 32 & 125 & 512 & - & 32 & 64 & 0.5 \\
\hline & $\mathrm{MBC}$ & 1024 & 16 & nd & nd & 64 & 125 & 1024 & - & 32 & 64 & 1 \\
\hline & $M B C / M I C$ & 1 & 1 & nd & nd & 2 & 1 & 2 & - & 1 & 1 & 2 \\
\hline \multirow[t]{3}{*}{ C. krusei } & $\mathrm{MIC}$ & 1024 & 64 & - & - & 32 & - & 256 & - & 64 & 64 & 2 \\
\hline & $\mathrm{MBC}$ & 1024 & 64 & nd & nd & 32 & - & 1024 & - & 64 & 64 & 2 \\
\hline & $M B C / M / C$ & 1 & 1 & nd & nd & 1 & - & 4 & - & 1 & 1 & 1 \\
\hline \multicolumn{13}{|c|}{ Fungi/Dermatophytes } \\
\hline \multirow[t]{3}{*}{ T. ajelloi } & MIC & 1024 & 16 & 16 & 4 & 4 & 4 & 512 & 4 & 32 & 64 & 4 \\
\hline & $\mathrm{MBC}$ & 1024 & 16 & 16 & 4 & 4 & 4 & 1024 & 4 & 32 & 64 & 4 \\
\hline & $M B C / M I C$ & 1 & 1 & 1 & 1 & 1 & 1 & 2 & 1 & 1 & 1 & 1 \\
\hline \multirow[t]{3}{*}{ T. rubrum } & MIC & 1024 & 32 & 128 & 16 & 8 & 32 & 256 & 64 & 8 & 32 & 4 \\
\hline & $\mathrm{MBC}$ & 1024 & 32 & 128 & 16 & 8 & 32 & 1024 & 64 & 8 & 32 & 4 \\
\hline & $M B C / M I C$ & 1 & 1 & 1 & 1 & 1 & 1 & 4 & 1 & 1 & 1 & 1 \\
\hline
\end{tabular}

Extract $^{\mathrm{a}}$ : EtOAc extract of the leaves of $P$. aurantiacum; Extract ${ }^{\mathrm{b}}: \mathrm{MeOH}$ extract of the leaves of $H$. lanceolatum; nd: not determined; -: not active at the concentration up to $128 \mu \mathrm{g} / \mathrm{ml}$ for compounds and $1024 \mu \mathrm{g} / \mathrm{ml}$ for extracts; RD (Reference drug) ciprofloxacin for bacteria, nystatin for yeast and griseofulvin for dermatophytes. 
Table 2 Radical Scavenging activity 50 values $(\mu \mathrm{g})$ of the methanol extracts and compounds from the leaves of $\boldsymbol{H}$. Lanceolatum and $P$. aurantiacum

\begin{tabular}{ll}
\hline Test substance & Rsa50 $(\boldsymbol{\mu g})$ \\
\hline H. lanceolatum extract & $30.99 \pm 0.87 \mathrm{e} P$ \\
\hline aurantiacum extract & $6.35 \pm 0.10 \mathrm{~b}, \mathrm{c}$ \\
\hline Isogarcinol & $1.01 \pm 0.24 \mathrm{~b}$ \\
\hline 1,3,6-trihydroxyxanthone & $4.73 \pm 0.80 \mathrm{~b}$ \\
\hline Kenganthranol B & $21.93 \pm 5.98 \mathrm{~d}$ \\
\hline 2,2',5,6'-tetrahydroxybenzophenone & na \\
\hline Physcion & na \\
\hline 1,8-dihydroxy-3-geranyloxy-6-methylanthraquinone & na \\
\hline Vismiaquinone & na \\
\hline L-ascorbic acid & $0.089 \pm 0.05 \mathrm{a}$ \\
\hline
\end{tabular}

Values with the same letter superscripts are not significantly different using Waller Duncan test at $\mathrm{p} \leq 0.05$. na: not active.

are presented in Table 1. In general, the crude extract of $H$. lanceolatum presented a wide range of activity and was more active than that of $P$. aurantiacum. Isogarcinol (11) and octacosanol (5) were the most active compounds with relatively high antibacterial activities, particularly on S. flexneri, K. pneumoniae and S. typhi while physcion (1) showed virtually no antimicrobial activity at the tested concentrations on bacteria. This is interesting in the perspective of developing more potent antibacterial agents especially when regarding the global diseases burden of the susceptible microorganisms [30,31]. Isogarcinol, a benzophenone derivative is known to possess cytotoxic effect [32].

In general, the antifungal activities of isolated compounds were relatively lower than their antibacterial activities. However, kenganthranol B (3), vismiaquinone (6), octacosanol (7) and betulinic acid (9) showed relatively high antidermatophytic activity particularly on $T$. ajelloi. Mbaveng et al. (2008) [33] previously demonstrated the antimicrobial properties of vismiaquinone isolated from Vismia guineensis and this corroborate the present study. The results obtained with kenganthranol B corroborate those of Kouam et al. (2006) [34] who reported that kenganthranol $\mathrm{E}$ possess no antibacterial activity against Bacillus megaterium, Escherichia coli, Chlorella fusca and Microbotryum violaceum. Despite the relatively low antimicrobial activity of kenganthranol $\mathrm{B}$, it has demonstrated, together with some of its isomers, to possess alpha-glucosidase inhibitory activity [34]. All the isolated compounds were generally less active than the reference antibiotics. The ratio MBC/MIC was generally $\leq 4$ with respect to all the microorganisms studied, indicative of a possible bactericidal nature of the test samples [35].

Many microbial infections lead to the production of highly reactive molecules from the metabolism of oxygen that can cause extensive damage to cells and tissues [36]. The extracts and isolated compounds exhibited differential radical scavenging activity against the stable DPPH free radical (Table 2 and Figure 2). At high concentrations $(12.5-50 \mu \mathrm{g} / \mathrm{ml})$ the activity of isogarcinol was comparable to that of L-ascorbic acid, the reference molecule. Although isogarcinol was isolated from $H$. lanceolatum, the crude extract of this plant showed a relatively low activity compared to that of $P$. aurantiacum. This may either be due to low concentration of this compound in the extract or to an antagonistic effect with other constituents of the extract. Isogarcinol is an isomeric form

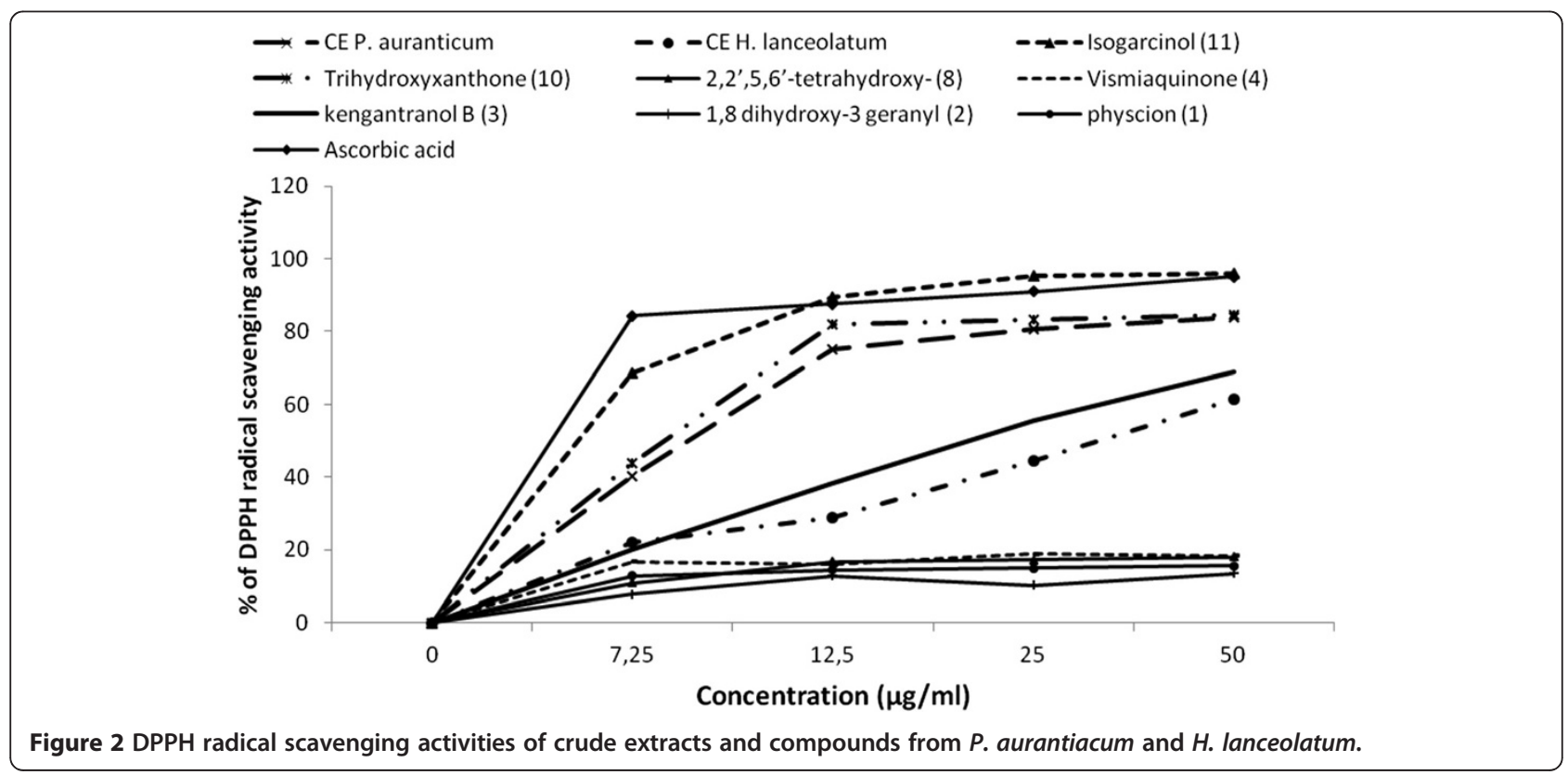


of garcinol, known to possess high antioxidant activity among many other properties [37].

\section{Conclusion}

The present findings support the ethno-pharmacological exploitation of these plants in the treatment of microbial infections and hold great perspective in the development of alternative antimicrobial and antioxidant agents from isogarcinol.

\section{Competing interests}

Authors declare that they do not have any competing interests.

\section{Authors' contributions}

PDT was the field investigator and drafted the manuscript. PKL revised the manuscript. TKK ANHL, LAT and PT carried out the isolation and characterization of compounds. HKW and JRK designed the study, supervised the work and corrected the manuscript. All authors read and approved the final manuscript.

\section{Acknowledgements}

We gratefully acknowledge financial support from the International Foundation for Science (IFS), Stockholm, Sweden, and the Organization for the Prohibition of Chemical Weapons, The Hague, Netherlands (IFS-OPCW, Grant No F/4901-1) to HKW.

\section{Author details}

'Laboratory of Microbiology and Antimicrobial Substances, Department of Biochemistry, Faculty of Science, University of Dschang, P.O. Box 67, Dschang, Cameroon. ${ }^{2}$ Department of Biochemistry, Faculty of Science, University of Yaounde 1, P.O. Box 812, Yaounde, Cameroon. ${ }^{3}$ Department of Chemistry, Faculty of Science, University of Dschang, P.O. Box 67, Dschang, Cameroon.

Received: 15 March 2012 Accepted: 14 August 2012 Published: 24 August 2012

\section{References}

1. Fenner R, Sortino M, Rates SMK, Dall'Agnol R, Ferraz A, Bernardi AP, Albring D, Nör C, von Poser G, Schapoval E, Zacchino S: Antifungal activity of some Brazilian Hypericum species. Phytomedicine 2005, 12:236-240.

2. Mukherjee KP, Saritha GS, Suresh B: Antimicrobial potential of two different Hypericum species available in India. Phytother Res 2002, 16:692-695.

3. Bhullar K, Waglechner N, Pawlowski A, Koteva K, Banks ED, Johnston MD, Barton HA, Wright GD: Antibiotic Resistance Is Prevalent in an Isolated Cave Microbiome. PLoS One 2012, 7(4):e34953. doi:10.1371.

4. Venkata SP, Murali MC, Prameela K, Sravani R, Raju BA: Screening of Antimicrobial and Antioxidant Potentials of Acacia caesia, Dillenia pentagyna and Buchanania lanzan from Maredumilli Forest of India. J Pharm Res 2012, 5(3):1734-1738.

5. Hutchinson J, Dalziel JM: Flora of West Tropical Africa (Revised by Keay RWJ). Part 1, Volume 1. 2nd edition. London and Tonbridge: The Whitefriars Press Ltd; 1954.

6. Kouam SF, Njonkou YLN, Kuigoua GM, Ngadjui BT, Hussain H, Green IR, Schulz B, Krohn K: Psorantin, a unique methylene linked dimer of vismin and kenganthranol $\mathrm{E}$, two anthranoid derivatives from the fruits of Psorospermum aurantiacum (Hypericaceae). Phytochem Lett 2010, 3:185-189.

7. Wabo HK, Kowa TK, Lonfouo AHN, Tchinda AT, Tane P, Kikuchi H, Frédérich M, Oshima Y: Phenolic compounds and terpenoids from Hypericum lanceolatum. Rec of Nat Pro 2012, 62:94-100

8. Dall'Agnol R, Ferraz A, Bernardi AP, Albring D, Nör C, Sarmento L, Lamb L, Hass M, von Poser G, Schapoval EES: Antimicrobial activity of some Hypericum species. Phytomedicine 2003, 10:511-516.

9. Kuete V, Nguemeving JR, Beng VP, Azebaze AGB, Etoa FX, Meyer M, Bodo B, Nkengfack AE: Antimicrobial activity of the methanolic extracts and compounds from Vismia laurentii De Wild (Guttiferae). J Ethnopharmacol 2007, 109:372-379.
10. Tsaffack MA, Nguemeving JR, Kuete $V$, Ndejouong TBS, Mkounga P, Beng VP, Hultin PG, Tsamo E, Nkengfack AE: Two new antimicrobial dimeric compounds: febrifuquinone, a vismione-anthraquinone coupled pigment and adamabianthrone, from two Psorospermum species. Chem Pharm Bull 2009, 57:1113-1118.

11. Tamokou JDD, Tala MF, Wabo HK, Kuiate JR, Tane P: Antimicrobial activity of methanol extract and compounds from stem bark of Vismia rubenscens. J Ethnopharmacol 2009, 124:571-575.

12. Gibbons S, Moser E, Hausmann S, Stavri M, Smith E, Clennett C: An antistaphylococcal acylphloroglucinol from Hypericum foliosum. Phytochemistry 2005, 66:1472-1475.

13. Shiu WKP, Gibbons S: Anti-staphylococcal acylphloroglucinols from Hypericum beanii. Phytochemistry 2006, 67:2568-2572.

14. Hong D, Yin F, Hu L-H, Lu P: Sulfonated xanthones from Hypericum sampsonii. Phytochemistry 2004, 65:2595-2598.

15. Martarelli D, Martarelli B, Pediconi D, Nabissi MI, Perfumi M, Pompei P: Hypericum perforatum methanolic extract inhibits growth of human prostatic carcinoma cell line orthotopically implanted in nude mice. Cancer Lett 2004, 210:27-33.

16. Jacobson JM, Feinman L, Liebes L, Ostrow N, Koslowski V, Tobia A, Cabana BE, Lee D, Spritzler J, Prince AM: Pharmacokinetics, safety, and antiviral effects of hypericin, a derivate of St. John's wort plant, in patients with chronic hepatitis C virus infection. Antimicrob Agents Chemother 2001, 45:517-524

17. Enugopal PV, Venugopal VT: Superficial mycoses in Saudi Arabia. Aust $J$ Dermatol 1992, 33:45-48

18. Zgoda JR, Porter JR: A convenient microdilution method for screening natural products against bacteria and fungi. Pharm Biol 2001, 39:221-225.

19. Tereschuk ML, Riere MVQ, Castro GR, Abdala LR: Antimicrobial activity of flavonoids from leaves of Tagetes minuta. J Ethnopharmacol 1997, 56:227-232.

20. Ghomi JS, Ebrahimabadi HA, Bidgoli DZ, Kashi JF, Batooli H: Bioactive properties of oil and methanol extracts of Pimpinella aurea Dc. Am Eurasian J of Sustain Agric 2008, 2:249-254.

21. Wabo HK, Kouam SF, Krohn K, Hussain H, Tala MF, Tane P, Ree T, Hu Q Schulz B: Prenylated anthraquinones and other constituents from the seeds of Vismia laurentii. Chem Pharm Bull 2007, 55:1640-1642.

22. Nguemeving JR, Azebaze AGB, Kuete V, Carly NNE, Penlap BV, Meyer M, Blond A, Bodo B, Nkengfack AE: Laurentixanthones A and B, antimicrobial xanthones from Vismia laurentii. Phytochemistry 2006, 67:1341-1346.

23. Tala MF, Krohn K, Hussain H, Kouam SF, Wabo HK, Tane P, Schulz B, Hu Q, Laurentixanthone C: A new antifungal and algicidal xanthone from stem bark of Vismia laurentii. Z Naturforsch 2007, 62b:565-568.

24. Venkatesan M, Viswanathan MB, Ramesh N, Lakshmanaperumalsamy P. Antibacterial potential from Indian Suregada angustifolia. J Ethnopharmacol 2005, 99:349-352

25. Akihisa T, Takamine Y, Yoshizumi K, Tokuda H, Kimura Y, Ukiya M, Nakahara T, Yokochi T, Ichiishi E, Nishino H: Microbial transformations of two lupane-type triterpenes and anti-tumor-promoting effects of the transformation products. J Nat Prod 2002, 65:278-282.

26. Nkengfack AE, Azebaze GA, Vardamides JC, Fomum ZT, Heerden FV: A prenylated xanthone from Allanblackia floribunda. Phytochemistry 2001, 60:381-384

27. Ohishi N, Suzuki T, Ogasawara T, Yagi K: Xanthone derivatives as inhibitors for monoamine oxidase. J Mol Catal B Enzym 2000, 10:291-294.

28. Matsumoto K, Akao Y, Kobayashi E, Ito T, Ohguchi K, Tanaka T, linuma M, Nozawa Y: Cytotoxic benzophenone derivatives from Garcinia species display a strong apoptosis- inducing effect against human leukemia cell lines. Biol Pharm Bull 2003, 26:569-571.

29. Zofou D, Kowa TK, Wabo HK, Ngemenya MN, Tane P, Titanji VPK: Hypericum lanceolatum (Hypericaceae) as a potential source of new anti-malarial agents: a bioassay-guided fractionation of the stem bark. Malar J 2011, 10:167. doi:10.1186/1475-2875-10-167.

30. WHO: The World Health Report 1996 - Fighting disease, fostering development. Geneva: World Health Organization; 1996.

31. Kouitcheu M, Penlap B, Kouam J, Ngadjui B, Fomum Z, Etoa F: Evaluation of antidiarrhoeal activity of the stem bark of Cylicodiscus gabunensis (Mimosaceae). Afr J Biotechnol 2006, 5:1062-1066.

32. Kenji M, Yukihiro A, Emi K, Tetsuro I, Kenji O, Toshiyuki T, Munekazu I, Yoshinori N: Cytotoxic Benzophenone Derivatives from Garcinia Species 
Display a Strong Apoptosis-Inducing Effect against Human Leukemia Cell Lines. Biol Pharm Bull 2003, 26:569-571.

33. Mbaveng AT, Kuete V, Nguemeving JR, Beng VP, Nkengfack AE, Meyer JM, Lall N, Krohn K: Antimicrobial activity of the extracts and compounds obtained from Vismia guineensis. Asian J Tradit Med 2008, 3:211-223.

34. Kouam SF, Khan SN, Krohn K, Ngadjui BT, Fotso DGWK: Alpha-glucosidase inhibitory anthranols, kenganthranols A-C, from the stem bark of Harungana madagascariensis. J Nat Prod 2006, 69:229-233.

35. Deshpande L, Rhomberg PR, Fritsche TR, Sader HS, Jones RN: Bactericidal activity of BAL9141, a novel parenteral cephalosporin against contemporary Gram-positive and Gram-negative isolates. Diagn Microbiol Infect Dis 2004, 50:73-75.

36. Kamlesh $D$, Yogesh $S$, Ajit P: Evaluation of in vitro antioxidant activity of Sida rhombifolia (L.) Ssp. Retusa (L.). J Med Food 2007, 10:683-688.

37. Padhye S, Ahmad A, Oswal N, Sarkar FH: Emerging role of Garcinol, the antioxidant chalcone from Garcinia indica Choisy and its synthetic analogs. J Hematol Oncol 2009, 2:38. doi:10.1186/1756-8722-2-38.

doi:10.1186/1472-6882-12-136

Cite this article as: Tchakam et al: Antimicrobial and antioxidant activities of the extracts and compounds from the leaves of

Psorospermum aurantiacum Engl. and Hypericum lanceolatum Lam.. BMC Complementary and Alternative Medicine 2012 12:136.

\section{Submit your next manuscript to BioMed Central and take full advantage of:}

- Convenient online submission

- Thorough peer review

- No space constraints or color figure charges

- Immediate publication on acceptance

- Inclusion in PubMed, CAS, Scopus and Google Scholar

- Research which is freely available for redistribution 